\title{
Differences and Impacts of Old-age Insurance System between Public Sectors and Enterprises
}

\author{
Sun Jianfu \\ College of Management \\ Hebei University \\ Baoding, R.R.China \\ E-mail: sunjianfu55@126.com
}

\author{
Wang Limin \\ College of Management \\ Hebei University \\ Baoding, R.R.China \\ E-mail: wanglimin@mohrss.gov.cn
}

\begin{abstract}
So far, China's Old-age Insurance System of States Organs and Public Institutions (SOPI) and that of Enterprises operate separately. This paper reviews the status of China's two-track system of old-age insurance, gives the differences in the system contents.
\end{abstract}

Keywords - old-age insurance; public sectors; enterprises.

\section{DIFFERENCES BETWEEN PUBLIC SECTORS AND ENTERPRISES}

As a social product, Social Old-age Insurance System which affects the vital interests to all citizens shall reflect the fair principle of non-discriminatory treatment. In order to reflect this principle, the system construction protecting the rights and interests of citizens shall cover all sectors of society. However, due to the complexity of basic conditions for the formation of China's Social Old-age Insurance System, it lacked co-ordinations at the beginning but was promoted and improved step and step gradually. In this context, the two-track system formed, namely Old-age Insurance System of SOPI and that of Enterprises operating parallelly. However, as time goes by, people working at different sectors enjoy different old-age insurances leads to sharp social contradictions, severely slowing down the pace of development of the Market Economic System. Therefore, in accordance with the objective requirements of the Construction of China's Old-age Insurance System, the pilot reform of the unification of two different systems has been carried out by Chinese Government in some provinces and cities. In China, Old-age Insurance System of SOPI and that of Enterprises operate separately. The differences between these two systems are as follows:

\section{A. Different Basic Modes}

For enterprise employees, a system of social pooling combined with individual account has already established after continuous reform and improvement. Social pooling which is compulsory refers to unified contribution, unified management and payment of Old-age Insurance funds. Individual account which is also compulsory is a "Special Fund through Individual's Pre-deposit”. The Government, employer and employee shall be jointly responsible for the implementation of Old-age Insurance relevant policies.
However, SOPI adopts the pay-as-you-go model which bases revenues on expenditures with slightly balances. It is a typical national security mode under which an employee does not contribute for retirement but all the responsibilities are borne by the State, and the employee can receive monthly pension after retirement.

\section{B. Different Ways of Raising Funds}

Old-age Insurance System of Enterprises has changed into partial accumulation mode from pay-as-you-go mode which was established at the beginning. After the transition, funds are collected from the enterprise and the employee separately and also are operated and administered respectively. In accordance with law, 20 percent of the total payroll collected from enterprise as Basic Old-age Insurance fees shall be fully pooled into social pooling funds. The employee shall contribute 8 percent of his/her average wage to individual account. Government will make fiscal policy to support the old-age insurance funds, and transfer the funds through budget adjustment to offset the over-expended part.

So far, no laws and regulations regarding individual contribution of employees in SOPI exists, so employees in SOPI will receive their pension after their retirement from the State or Government directly.

\section{Different Qualifying Conditions}

Any Enterprise employee who wants to receive old-age insurance payment shall meet the following requirements: a. the person has reached the statutory retirement age and gone through procedures for retirement. b. The enterprise and the individual employee have participated in the old-age insurance program and paid contributions as stipulated by law. c. The number of years of the person's contribution is no less than 15 years. Any employee who fails to meet the above-said requirements, he/she may be paid the amount in one lump sum equivalent to the savings from his/her Individual Account by the Social Insurance Agency.

The Qualifying conditions for employees in SOPI to receive old-age insurance payment is "to reach statutory retirement age and length of service is no less than 10 years”. 


\section{Different Calculation and Payment}

Old-age Insurance System of Enterprises is a defined contribution system within which an employee may receive more pension if the years of his/her contribution is longer and the payment base is higher, and otherwise lower.

Any employee whose years of contribution is no less than 15 years may receive monthly pension after retirement. The benefits of employee's basic old-age insurance are composed of basic pension and individual account pension. The amount of the basic pension is based on the mean between monthly average wage of local on-job employees and indexation of monthly average contributory wage of the beneficiary. The beneficiary will be entitled to $1 \%$ of the base amount per year of contribution. The individual account pension equals to the total balance of the account divided by the number of pensionable months.

Pension of employees in SOPI is calculated and paid in a different way, shown in Table1.

TABLE I. DIFFERENCE BETWEEN PENSION's CALCUlATION AND PAYMENT OF EMPLOYEES

\begin{tabular}{|l|c|c|}
\hline \multirow{2}{*}{$\begin{array}{c}\text { Length of } \\
\text { Service }\end{array}$} & $\begin{array}{c}\text { Employees in State } \\
\text { Organs * }\end{array}$ & $\begin{array}{c}\text { Head Employees in } \\
\text { Public Institutions ** }\end{array}$ \\
\cline { 2 - 3 } 10 years and less & Percentage (\%) & Percentage (\%) \\
\hline $10-20$ years & 40 & 50 \\
\hline 20-30 years & 60 & 70 \\
\hline $30-35$ years & 75 & 80 \\
\hline 35 years above & 82 & 85 \\
\hline
\end{tabular}

* Basic wage and seniority pay are paid in full, and post wage and level of wage are paid in accordance with the following proportions.

** Percentage of the sum of post wage and allowance

In addition, the adjusting mechanisms of Old-age Insurance System of SOPI and that of Enterprise Employees are also different.

\section{THE IMPACT OF THE OPERATION OF CHINA'S TWO- TRACK SYSTEM OF OLD-AGE INSURANCE}

Before you begin to format your paper, first write and save the content as a separate text file. Keep your text and graphic files separate until after the text has been formatted and styled. Do not use hard tabs, and limit use of hard returns to only one return at the end of a paragraph. Do not add any kind of pagination anywhere in the paper. Do not number text heads-the template will do that for you.

Finally, complete content and organizational editing before formatting. Please take note of the following items when proofreading spelling and grammar:

\section{A. Growing gap between pension of employees in SOPI and that of Enterprises}

There is a growing gap between pension of employees in SOPI and that of Enterprises. In 1990, as shown in Table 3-1, the per capita pension of an Enterprise retired employee was 1664 RMB, while 1889 RMB for a retired employee in
Public Institutions and 2006 RMB for a retired employee in State Organs. The gap was not particularly large at that time. In 2005, the per capita pension in Enterprises, Public Institutions and State Organs was 8803 RMB, 16425 RMB and $18140 \mathrm{RMB}$ respectively. The per capita pension in Public Institutions was $86.6 \%$ higher than that in Enterprises while per capita pension in State Organs was 109.1\% higher than that in Enterprises. It was obvious that the gap became very large. The growth rate of the per capita pension of employees in SOPI was significantly higher than that in Enterprises.

Comparing the relative gap, if the per capita pension of SOPI is divided by the per capita pension of Enterprises, we get Table 3-2. It is apparent that, the relative gap of the per capita pension between that of enterprises and that of State Organs and Pubic Institutions shows a yearly widening trend. In 1990, the per capita pension of State Organs is 1.21 times of that of Enterprises; to 2005, the per capita pension of State Organs up to 2.09 times of that of Enterprises, the gap between the two average annual rates is widen by the speed of $6.8 \%$. Similarly, in 1990, the per capita pension of Public Institutions is 1.14 times of that of Enterprises, to 2005, the per capita pension of Public Institutions up to 1.87 times of that of Enterprise, the gap between the two average annual rates is widen by the speed of $5.4 \%$.

\section{B. $\quad$ The Old-age Insurance System of SOPI results in a heavy financial burden}

In the Old-age Insurance System of SOPI, an employee is not required to make any contribution, but he/she may receive the monthly pension after his/her retirement if he/she has working for a certain number of years. In the context of current market economy, such social security system causes tremendous pressure to state fiscal situation, and seriously hinders the economic and social development of our country. As shown in Table 3-1, in 1990, the total cost of the per capita pension of SOPI was 8.18 billion RMB, which increased to 182.77 billion RMB in 2005, it increased 21 times in 16 years, with an average annual growth of $23.6 \%$, including growth up to $62.5 \%$ in 1994.Equations

\section{The Two System Cannot be Connected}

As the Old-age Insurance Systems of Enterprises and that of SOPI are different in contribution, calculation and payment, tend follow-up management. The two systems cannot be connected properly, so workers cannot flow freely within the country, which greatly hinders the development of Chinese labor market, and deepens the distorting effects of Social Security system to the labor market.

\section{REFERENCES}

[1] B. W. Zheng, S. J. Sun, and Z. J. Qi,. "Thinking of Civil servants to Participate in the Reform of the Pension Insurance-"Hybrid" System Combined with System Account Estimates". Journal of Public Administration, 2009, (2):127-137J.

[2] Y. Q. Long,. Civil Service Pension Insurance System International Comparison, Beijing: Social Sciences Press, 2012. 